\title{
Determinations of photosynthetic capacity in coastal marine phytoplankton: effects of assay irradiance and variability of photosynthetic parameters
}

\author{
J. R. Forbes, K. L. Denman \& D. L. Mackas \\ Institute of Ocean Sciences, P. O. Box 6000, Sidney, British Columbia V8L 4B2, Canada
}

\begin{abstract}
Results from photosynthesis versus irradiance $[\mathrm{P}(\mathrm{I})]$ experiments are used to examine the effects of variability in photosynthetic parameters on determinations of the photosynthetic capacity $\left(\mathrm{P}_{\mathrm{m}}^{\mathrm{B}}\right)$ of natural phytoplankton populations in coastal waters. No significant difference was found in the relation between $\mathrm{P}_{\mathrm{m}}^{\mathrm{B}}$ and the initial slope of the $\mathrm{P}(\mathrm{I})$ curve $(\alpha)$ over a broad range of sampling distance, time, water column stability and in situ PAR, illustrating the utility of $\mathrm{P}_{\mathrm{m}}^{\mathrm{B}}$ as an index of photoadaptation for comparing populations. Diel oscillations of photosynthetic parameters were sinusoidal in these populations. Variability in phase, amplitude and form of the diel cycle requires that these be determined on a spatial and temporal scale appropriate to the survey at hand. We developed methods to estimate photosynthetic capacity with associated confidence limits at a single light level that need not be saturating. The same techniques are applicable to estimation of $\alpha$ at a single assay irradiance. Precision in estimates of $\alpha$ is important when estimates are to be made of integrated production, as this is particularly sensitive to errors in $\alpha$. We show that confidence limits are minimized for estimates of $P_{m}^{B}$ when the irradiance used is closest to the mean irradiance at which $\mathrm{P}_{\mathrm{m}}^{\mathrm{B}}$ occurs in the population. Confidence limits for estimates of $\alpha$ are minimized when the lowest light level commensurate with suitable precision in the photosynthetic rate measurements is used. These techniques provide for the reliable estimation of $\mathrm{P}_{\mathrm{m}}^{\mathrm{B}}$ or $\alpha$ in situations where a rapid sampling rate is required to investigate photosynthetic response over short time or space scales.
\end{abstract}

\section{INTRODUCTION}

The response of phytoplankton to dynamic physical processes is frequently characterized by indices of photoadaptation of the phytoplankton populations. These indices are typically variables equivalent to or derived from the photosynthetic parameters of photosynthesis versus irradiance $[\mathrm{P}(\mathrm{I})]$ experiments. The $\mathrm{P}(\mathrm{I})$ parameters may also be used, in conjunction with chlorophyll profiles and sub-surface irradiance or light attenuation data, for calculating integrated primary production over depth. Where a rapid sampling rate is required to investigate photosynthetic response over short time or space scales, it may be advantageous to bypass the full $\mathrm{P}$ (I) protocol and perform photosynthetic rate measurements at a single light level, from which indices of photoadaptation can be inferred.

Photosynthetic capacity is one index commonly used for comparisons between populations (e.g. Malone
1971, Gargas et al. 1980, Demers \& Legendre 1982). In this paper we examine the impact of variability of photosynthetic parameters and their inter-relations on estimates of the photosynthetic capacity of natural phytoplankton populations. We focus on comparisons between populations in several regions of the Pacific coast of Canada and on diel cycles of parameters. We also establish methods of estimating photosynthetic capacity, and associated confidence limits, from photosynthetic rate measurements at assay light levels that need not be saturating. The index of photosynthetic capacity used here is the maximum realized rate of photosynthesis $\left(\mathrm{P}_{\mathrm{m}}^{\mathrm{B}}\right)$ normalized to chlorophyll concentration. This is one of the standard photosynthetic parameters derived from $\mathrm{P}(\mathrm{I})$ experiments and is equivalent to an assimilation number. A similar analysis is performed to establish criteria for estimating the initial slope of the $\mathrm{P}(\mathrm{I})$ curve $(\alpha)$, also normalized to chlorophyll concentration, from photosynthetic rate 
measurements at a single assay light level, as well as the confidence limits associated with such estimates.

The utility of $\mathrm{P}_{\mathrm{m}}^{\mathrm{B}}$ for comparing populations has been demonstrated by Harrison \& Platt (1980), who demonstrated that it is sensitive to a wide range of environmental and biological variables. Côté \& Platt (1984) have shown that the effects of transient physical phenomena, such as storms and periods of upwelling, are reflected in changes in photosynthetic parameters, but may not be seen in instantaneous rate measurements. An index of photoadaptation, such as photosynthetic capacity, may thus not only permit frequent estimation, but may also define response to a dynamically changing physical environment better than the standard techniques for measuring primary production, such as in situ incubations or simulated in situ methods.

A number of studies have demonstrated a correlation between $\mathrm{P}_{\mathrm{m}}^{\mathrm{B}}$ and $\alpha$ (e.g. Harding et al. 1982a, 1983, Côté \& Platt 1983). The implications of such a correlation are important if $P_{m}^{B}$ is intended to be used as an index of phytoplankton response to environmental variables, because covariation of $\mathrm{P}_{\mathrm{m}}^{\mathrm{B}}$ and $\alpha$ implies a similar variation in the photosynthetic rate at any specified irradiance $\left[\mathrm{P}^{\mathrm{B}}(\mathrm{I})\right]$. In populations where $\mathrm{P}_{\mathrm{m}}^{\mathrm{B}}$ and $\alpha$ are correlated, knowledge of $P_{m}^{B}$ alone confers a large amount of information about the photoadaptive condition of the population. Harding et al. (1982) concluded that the consistent relation between the 2 parameters allows documentation of the entire diel range of photosynthetic response from closely-spaced determinations of $\mathrm{P}_{\mathrm{m}}^{\mathrm{B}}$. Estimates of daily production, when diel variation is taken into account, may then be inferred from $\mathrm{P}_{\mathrm{n}}^{\mathrm{B}}$, chlorophyll and sub-surface irradiance or attenuance data alone.

Lewis et al. (1985) compared the effect of errors in the determination of $\mathrm{P}_{\mathrm{m}}^{\mathrm{B}}$ and $\alpha$ on estimates of depthintegrated photosynthesis derived from these parameters. They demonstrated that, in most conditions, errors in the initial slope will have a greater effect on estimates of integrated photosynthesis than comparable errors in the maximum rate. This suggests that, where the purpose of the investigation is to estimate integrated primary production, it is more useful to obtain good estimates of $\alpha$ than of $\mathrm{P}_{\mathrm{m}}^{\mathrm{B}}$.

Our analysis is based on experimental determinations of the photosynthetic response of phytoplankton to irradiance $[\mathrm{P}(\mathrm{I})$ experiments] in Pacific coastal waters of Canada. Additional data from Ocean Station $P$ in the Northeast Pacific Ocean contribute to establishing methods for determining errors. Detailed results of experiments in coastal waters are available in Forbes et al. (1983) and ancillary station data from the Hecate Strait area are available in Denman et al. (1985).

\section{METHODS}

Sampling. Experiments were carried out in the Strait of Georgia and Saanich Inlet in May 1983, in Hecate Strait and other coastal regions in July 1983, and at Ocean Station P $\left(50^{\circ} \mathrm{N}, 145^{\circ} \mathrm{W}\right)$ in May 1984 (Fig. 1)

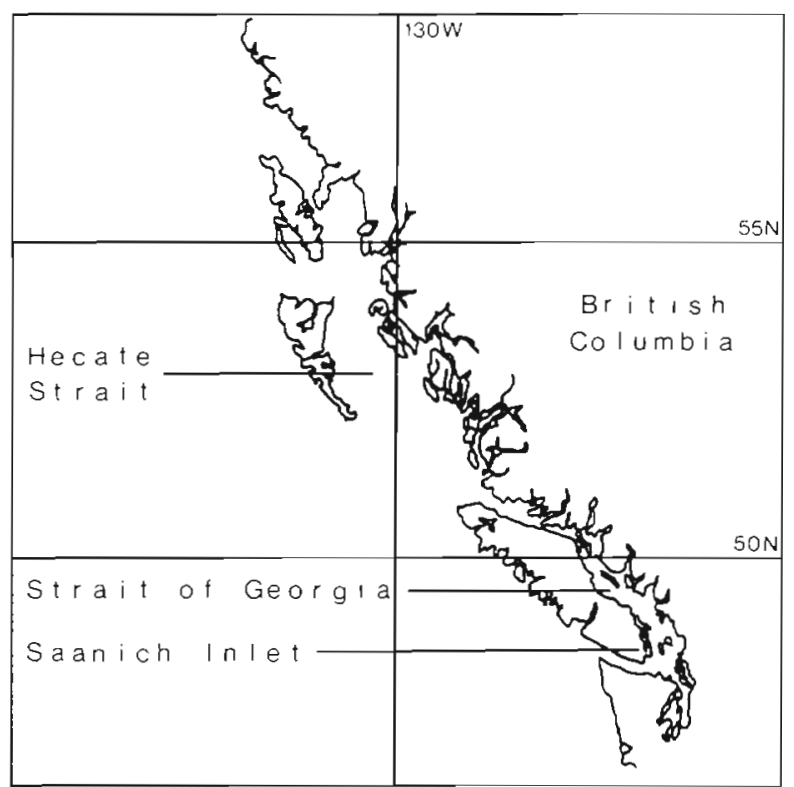

Fig. 1. Locations of Saanich Inlet, the Strait of Georgia and Hecate Strait

Samples were collected with a rosette sampler equipped with electronic sensors to measure conductivity. temperature, depth, fluorescence, beam attenuance and photosynthetically active quantum scalar irradiance (PAR). Details of these sensors, including their estimated precision and accuracy, are described in Denman et al. (1985).

Samples were taken from the depth within the upper mixed layer having the greatest chlorophyll fluorescence, as determined by the profiling in situ fluorometer. Samples for nutrient analysis were drawn first from the Niskin bottles. Then, to avoid excessive exposure to surface illumination, water for photosynthetic rate measurements, pH and chlorophyll a analysis was drawn directly into large, dark bottles for subsampling in the ship's laboratory.

Photosynthetic rate measurements and $P(I)$ experimental methods. Uptake of ${ }^{14} \mathrm{C}$ was determined by a modified version of the method of Strickland \& Parsons (1972). Subsamples $(60 \mathrm{ml})$ were incubated in an incubator with a $1000 \mathrm{~W}$ tungsten-halogen lamp. Spectral composition was mediated with a blue plexiglass filter (Rohm and Haas 2069) and light level was controlled by various levels of neutral density screening. The incubator provided a range of PAR levels for 
light bottles between 7 and $1725 \mu$ Ein $\mathrm{s}^{-1} \mathrm{~m}^{-2}$, as measured by a Biospherical Instruments QSL100 quantum sensor. Subsamples to measure dark uptake were taped and covered with aluminum foil before being placed in the incubator. Temperature was controlled within $1 \mathrm{C}^{\circ}$ of in situ temperature with a recirculating refrigeration system. Subsamples were incubated for $1 \mathrm{~h}$, then filtered onto $0.45 \mu \mathrm{m}$ pore size membrane filters (Millipore HA). These were fumed over concentrated $\mathrm{HCl}$ for $1 \mathrm{~min}$ and placed in scintillation vials with $15 \mathrm{ml}$ Aquasol LSC cocktail (New England Nuclear). Activity was measured later in the laboratory with an L.KB 1217 liquid scintillation counter, with counting efficiency determined by the channels ratio method. The mean dark uptake for each experiment was subtracted from the light uptake values.

The tables of Strickland \& Parsons (1972) were used to derive dissolved inorganic carbon from total alkalinity. Specific alkalinity and seawater density were assumed to be 0.123 and 1.025 respectively. The latter is required in the conversion of specific to total alkalinity. In the Strait of Georgia, where brackish water was encountered at many stations, total alkalinity was determined by the $\mathrm{pH}$ method (Grasshoff 1976). The necessary in situ temperature and salinity values were obtained from CTD profiles.

$\mathrm{P}$ (I) data were fitted to the model of Platt et al. (1980):

$$
\mathrm{P}^{\mathrm{B}}(\mathrm{I})=\mathrm{P}_{s}^{\mathrm{B}}\left(1-\mathrm{e}^{-\alpha / / P_{s}^{\mathrm{B}}}\right) \mathrm{e}^{-\mathrm{Bl} / \mathrm{P}_{s}^{\mathrm{B}}}
$$

All photosynthetic rate measurements were normalized to chlorophyll concentration, denoted by the superscript $\mathrm{B} . \mathrm{P}^{\mathrm{B}}(\mathrm{I})=$ photosynthetic rate at irradiance $I_{i} P_{s}^{B}=$ light saturated photosynthetic rate of the population in the absence of photoinhibition; $\alpha=$ initial slope of the $\mathrm{P}$ (I) curve, corresponding to the light reaction rate; $\beta=$ an index of apparent photoinhibition.

The maximum realized photosynthetic rate, $\mathrm{P}_{\mathrm{m}}^{\mathrm{B}}$ and the light level $I_{m}$ at which $P^{B}\left(I_{m}\right)=P_{m}^{B}$ were derived using:

$$
\begin{gathered}
\mathrm{P}_{\mathrm{m}}^{\mathrm{B}}=\mathrm{P}_{\mathrm{s}}^{\mathrm{B}}(\alpha /[\alpha+\beta])(\beta /[\alpha+\beta])^{(\beta / \alpha)} \\
\mathrm{I}_{\mathrm{m}}=\mathrm{P}_{\mathrm{s}}^{\mathrm{B}} / \alpha \log _{e}([\alpha+\beta] / \beta)
\end{gathered}
$$

(Platt et al. 1980). Note that $\mathrm{P}_{\mathrm{m}}^{\mathrm{B}}=\mathrm{P}_{\mathrm{s}}^{\mathrm{B}}$ and $\mathrm{I}_{\mathrm{m}}$ is undefined where $\beta=0$. The implications of this are discussed below.

The units of $\mathrm{P}^{\mathrm{B}}(\mathrm{I}), \mathrm{P}_{\mathrm{s}}^{\mathrm{B}}$ and $\mathrm{P}_{\mathrm{m}}^{\mathrm{B}}$ are $\mathrm{mg} \mathrm{C}(\mathrm{mg} \mathrm{Chl} \mathrm{a})^{-1}$ $h^{-1}$; the units of $I$ and $I_{m}$ are $\mu$ Ein $s^{-1} \mathrm{~m}^{-2}$; the units of $\alpha$ and $\beta$ are $\mathrm{mg} C(\mathrm{mgChl} a)^{-1} \mathrm{~h}^{-1}\left(\mu \text { Ein } \mathrm{s}^{-1} \mathrm{~m}^{-2}\right)^{-1}$.

Chlorophyll a analysis. Replicate determinations of extracted chlorophyll a were obtained by fluorometry (Holm-Hansen et al. 1965). Samples were filtered with approximately $0.5 \mathrm{ml} \quad 1 \% \mathrm{MgCO}_{3}$ suspension onto glass fibre filters (Whatman 934AH) and extracted in $90 \%$ aqueous acetone. Fluorescence was measured before and after acidification in a Turner Designs 10 fluorometer. We calculated chlorophyll a using the equations of Strickland \& Parsons (1972).

\section{RESULTS}

\section{Covariation of $\mathrm{P}_{\mathrm{m}}^{\mathrm{B}}$ and $\alpha$}

We found considerable variation in the maximum photosynthetic rate, $\mathrm{P}_{\mathrm{m}}^{\mathrm{B}}$, and the initial slope, $\alpha$, between regions. Mean $\mathrm{P}_{\mathrm{m}}^{\mathrm{B}} \pm 1 \mathrm{SE}$ was $5.0 \pm 0.4 \mathrm{mg} \mathrm{C}$ $(\mathrm{mg} \mathrm{Chl} \mathrm{a})^{-1} \mathrm{~h}^{-1}$ in Saanich Inlet, $7.5 \pm 0.6 \mathrm{mg} \mathrm{C}(\mathrm{mg}$ $\mathrm{Chl} \mathrm{a})^{-1} \mathrm{~h}^{-1}$ in Hecate Strait and $12.3 \pm 1.0 \mathrm{mg} \mathrm{C}(\mathrm{mg}$ Chl a) $)^{-1} h^{-1}$ in the Strait of Georgia. Mean $\alpha$ values for the 3 regions were $0.042 \pm 0.003,0.056 \pm 0.004$ and $0.079 \pm 0.005 \mathrm{mg} \mathrm{C}(\mathrm{mgChl} \mathrm{a})^{-1} \mathrm{~h}^{-1}\left(\mu \text { Ein s} \mathrm{s}^{-1} \mathrm{~m}^{-2}\right)^{-1}$ respectively.

Functional or neutral regressions (Ricker 1973) were calculated between $\alpha$ and $\mathrm{P}_{\mathrm{m}}^{\mathrm{B}}$. This type of regression takes as the slope the geometric mean of the slopes of $y$ regressed on $x$ and of $x$ regressed on $y$, to be used when both variables contain uncertainty. $\mathrm{P}_{\mathrm{m}}^{\mathrm{B}}$ was significantly correlated with $\alpha(\mathrm{p}<0.01)$ in all regions separately and collectively (Fig. 2, Table 1); the strongest correlation was found for all data combined in one regression. Nevertheless, the separate regression lines were compared using the test for equality of slopes (Draper \& Smith 1966), modified to test geometric mean slopes. The analysis of variance determined that there was no significant difference between the 3 slopes $(p<0.05)$. The geometric mean slope of the combined data was $7.04 \times 10^{-3}\left(\mu \operatorname{Ein~s}^{-1} \mathrm{~m}^{-2}\right)^{-1}(\mathrm{r}=$ 0.84, $\mathrm{n}=61$ ) (Fig. 2).

In the majority of experiments, $\beta$ was not significantly different from zero, within the $90 \%$ confidence limits calculated for $\beta$ independently of the other parameters. This resulted in a strong correlation between $P_{s}^{B}$ and $P_{m}^{B}(r=0.97, n=72)$.

Table 1 . Slopes (in units of $\left[\mu \text { Ein } s^{-1} \mathrm{~m}^{-2}\right]^{-1}$ ), sample sizes $(\mathrm{n})$ and correlation coefficients $(r)$ for functional regressions of $\alpha$ with $\mathrm{P}_{\mathrm{m}}^{\mathrm{B}}$

\begin{tabular}{|lccc|}
\hline \multicolumn{1}{c}{ Region } & Slope & $\mathrm{n}$ & $\mathrm{r}$ \\
\hline Strait of Georgia & $6.344 \times 10^{-3}$ & 13 & 0.69 \\
Saanich Inlet & $8.226 \times 10^{-3}$ & 24 & 0,68 \\
Hecate Strait & $7.338 \times 10^{-3}$ & 24 & 0.76 \\
Combined data & $7.035 \times 10^{-3}$ & 61 & 0.84 \\
\hline
\end{tabular}



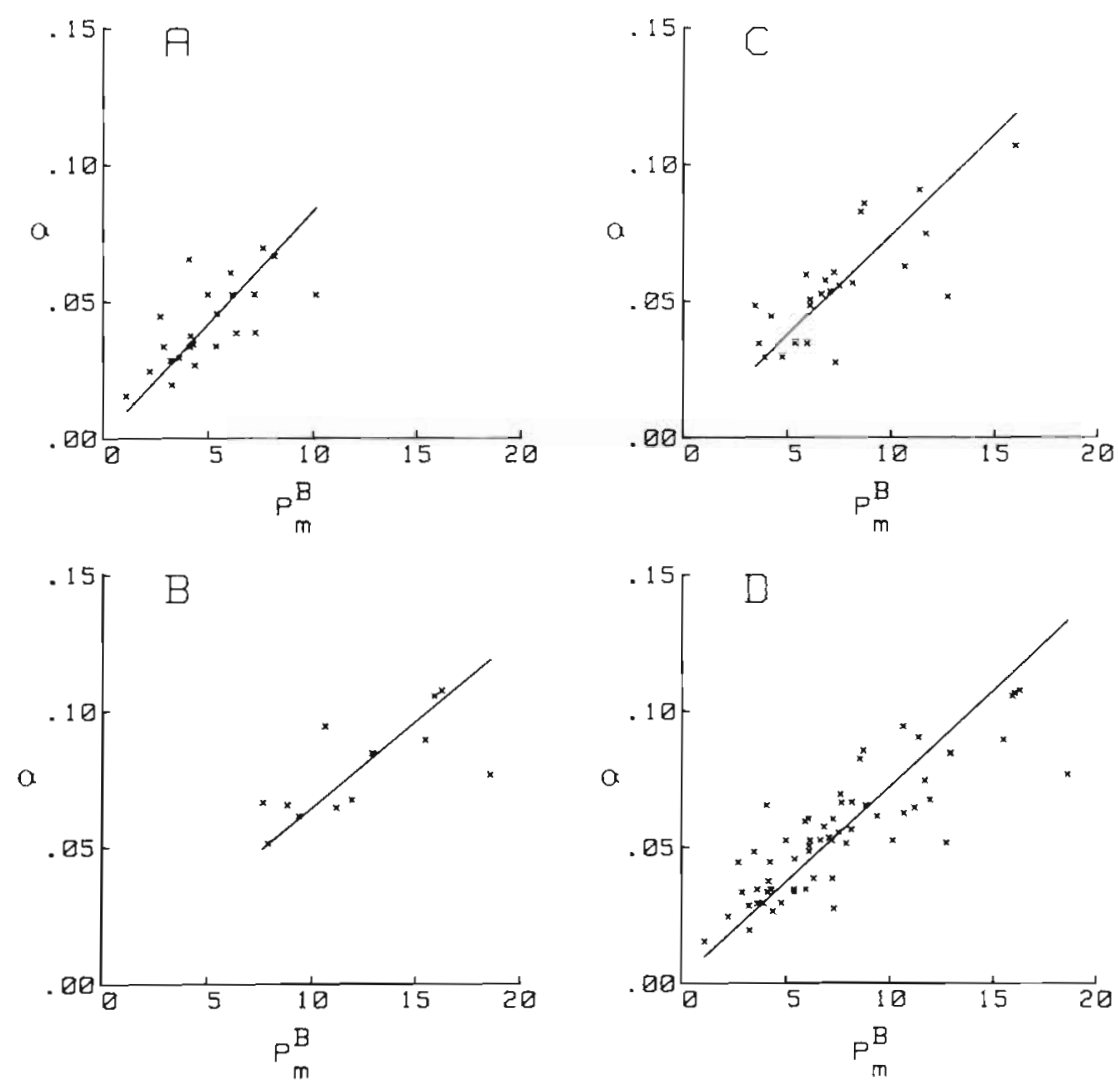

Fig. 2. Functional regressions of $\alpha$ with $P_{m}^{B}$ for Saanich Inlet (A), the Strait of Georgia (B), Hecate Strait (C) and combined coastal data (D). Units for $\alpha$ and $\mathrm{P}_{\mathrm{m}}^{B}$ are $\mathrm{mg} \mathrm{C}(\mathrm{mg} \mathrm{Chl} a)^{-1} \mathrm{~h}^{-1}\left(\mu\right.$ Ein $\mathrm{s}^{-1}$ $\left.\mathrm{m}^{-2}\right)^{-1}$ and $\mathrm{mg} \mathrm{C}(\mathrm{mg} \mathrm{Chl} \mathrm{a})^{-1} \mathrm{~h}^{-1}$ respectively

\section{Diel variability of photosynthetic parameters}

We performed time series of $\mathrm{P}(\mathrm{I})$ experiments in all 3 coastal areas to determine the amplitude of diel variations in photosynthetic parameters and to assess the form of their cycles. Repeated sampling for P(I) determinations was carried out at $3 \mathrm{~h}$ intervals, over $24 \mathrm{~h}$ or longer, at 2 stations in Saanich Inlet, 2 stations in Hecate Strait, and following a drogue deployed near the Fraser River plume convergence in the Strait of Georgia. Similar diel periodicity of $\mathrm{p}_{\mathrm{s},}^{\mathrm{B}} \mathrm{P}_{\mathrm{m}}^{B}$ and $\alpha$ was observed in all time series, with peak values occurring uniformly during late morning.

Data for each time series were normalized by the maximum value of that time series, and combined for each of $\mathrm{P}_{\mathrm{s}}^{\mathrm{B}} \mathrm{P}_{\mathrm{m}}^{\mathrm{B}}$ and $\alpha$. The normalized, combined data for each coefficient are presented in Fig. 3. Data were fitted to the model of McCaull \& Platt (1977):

$$
v(t)=b_{m}+b_{a} 2^{-n}\left[1+\cos (2 \pi / 24)\left(t-b_{p}\right)\right]^{n}
$$

where $b_{m}=$ minimum value of the parameter $v$ (normalized in this case); $b_{a}=$ amplitude; $b_{p}=$ phase $(h)$, expressed as the local apparent time at which $\mathrm{v}(\mathrm{t})$ is at its maximum; $\mathrm{n}=$ integer controlling departure from sine curve; $\mathrm{t}=$ local apparent time $(\mathrm{h})$.
Fitted values of parameters, listed in Table 2, showed no strong departure from a sine curve $(n=1)$ by $\mathrm{P}_{\mathrm{s}}^{\mathrm{B}} \mathrm{P}_{\mathrm{m}}^{\mathrm{B}}$ or $\alpha$ (Fig. 3). The best fit for $\mathrm{P}_{\mathrm{s}}^{\mathrm{B}}$ and $\mathrm{P}_{\mathrm{m}}^{\mathrm{B}}$ was obtained for $n=1$. A slightly better fit for $\alpha$ was obtained with $n=2$, indicating a slight departure from the sine curve. Estimated amplitude and phase were similar for all 3 parameters. $\mathrm{P}_{\mathrm{s}}^{\mathrm{B}}$ peaked at $1109 \mathrm{~h}$ (local apparent time), $\mathrm{P}_{\mathrm{m}}^{\mathrm{B}}$ at $1121 \mathrm{~h}$ and $\alpha$ at $1126 \mathrm{~h}$. The normalized amplitudes of $\mathrm{P}_{5}^{\mathrm{B}}$ and $\mathrm{P}_{\mathrm{m}}^{\mathrm{B}}$ were similar: 0.45 and 0.46 respectively, while $\alpha$ showed a smaller difference between maximum and minimum daily values: 0.36. A similar analysis of $I_{m}, I_{s}\left(=\mathrm{P}_{s}^{\mathrm{B}} / \alpha\right)$ and $I_{k}\left(=\mathrm{P}_{\mathrm{m}}^{\mathrm{B}} /\right.$ $\alpha)$, all with units of $\mu$ Ein $\mathrm{s}^{-1} \mathrm{~m}^{-2}$, showed no evidence of a daily cycle ( $I_{m}$ illustrated in Fig. 3). One datum point from a Saanich Inlet series was omitted from this analysis as it was affected by an early-afternoon depression of photosynthesis.

Table 2. Estumated values for parameters of the diel cycles of $\mathrm{P}_{s}^{\mathrm{B}}, \mathrm{P}_{\mathrm{n}}^{\mathrm{B}}$ and $\alpha$ (all time series combined)

\begin{tabular}{cccc|}
\hline Parameter & $\mathrm{b}_{\mathrm{m}}$ & $\mathrm{b}_{\mathrm{d}}$ & $\mathrm{b}_{\mathrm{p}}$ (local apparent time) \\
\hline $\mathrm{P}_{s}^{\mathrm{B}}$ & .463 & .449 & $1109 \mathrm{~h}$ \\
$\mathrm{P}_{\mathrm{r}}^{\mathrm{E}}$ & .452 & .458 & $1121 \mathrm{~h}$ \\
$\alpha$ & .496 & .359 & $1126 \mathrm{~h}$ \\
\hline
\end{tabular}



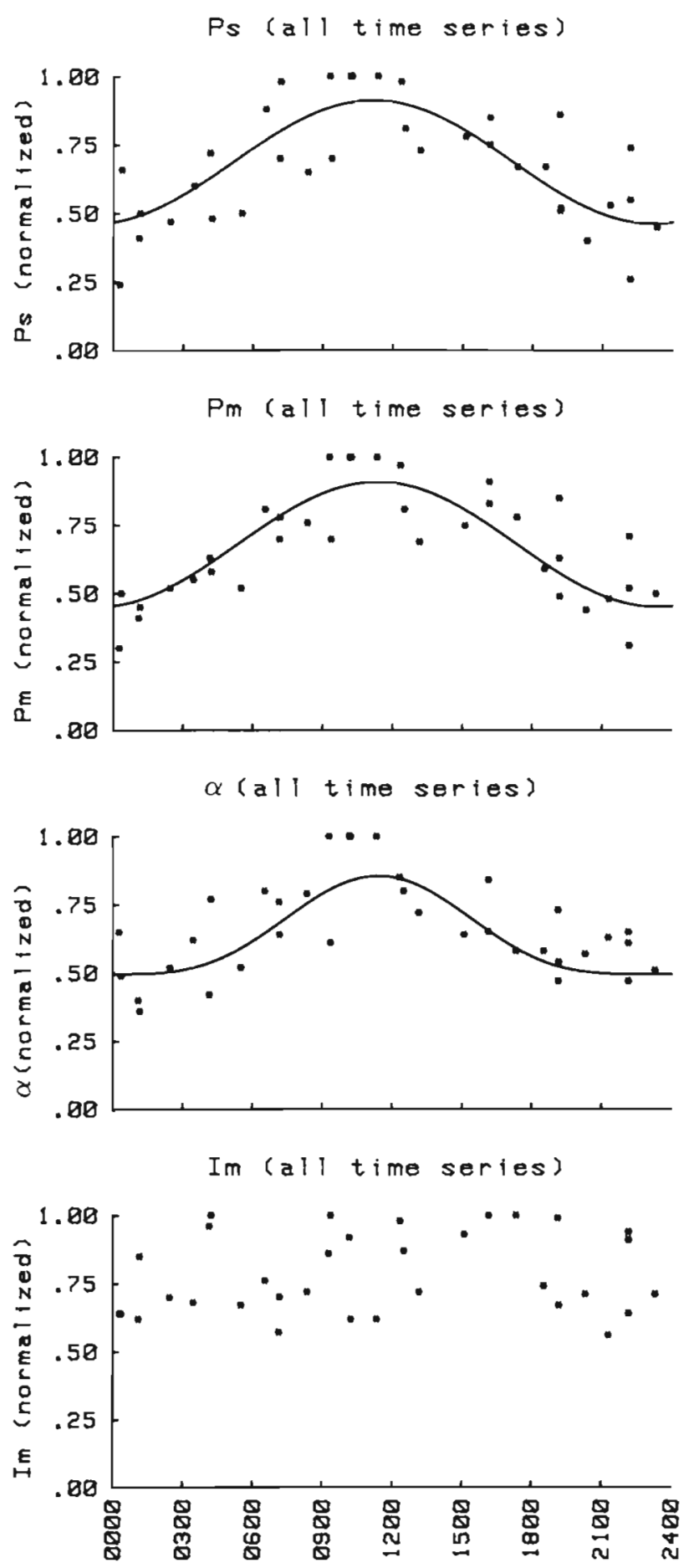

Local Apparent Time

Fig. 3. Normalized, combined time series of $P_{s}^{B}, P_{m}^{B}, \alpha$ and $I_{m}$, with fitted sine curve for $\mathrm{P}_{s}^{\mathrm{B}}$ and $\mathrm{P}_{\mathrm{m}}^{\mathrm{B}}$, and fitted sinusoidal $(n=2)$ curve for $\alpha$
Estimation of $\mathbf{P}_{\mathrm{m}}^{\mathrm{B}}$ and $\alpha$ from incubations at specified light levels and determination of errors in estimates

To obtain sufficient measurements to resolve the diel variation in $P_{m}^{B}$ or to establish the spatial variability of $\mathrm{P}_{\mathrm{m}}^{\mathrm{B}}$ over some moderate spatial scale, it is desirable to estimate $P_{\mathrm{m}}^{\mathrm{B}}$ from incubations at a single specified light intensity I. Two sources of error affect such estimates. The first is the precision of determinations of $\mathrm{P}^{\mathrm{B}}(\mathrm{I})$. The second involves an appropriate choice of I. With prior knowledge of $I_{m}$ assay I may be set to $I_{m}$. Otherwise the errors associated with estimates of $\mathrm{P}_{\mathrm{m}}^{\mathrm{B}}$ based on measurements of $\mathrm{P}^{\mathrm{B}}(\mathrm{I})$ at values of $\mathrm{I}$ other than $\mathrm{I}_{\mathrm{m}}$ must be determined. The latter approach is more suitable as in practice $I_{m}$ can only be determined after the fact, through analysis of full $\mathrm{P}(\mathrm{I})$ experiments, and experimental protocol is simplified by incubating all samples at a single light level.

The precision of determinations of $\mathrm{P}^{\mathrm{B}}(\mathrm{I})$ is dependent on experimental conditions specific to the method, and can be derived from the pooled standard deviation of replicate samples through a range of $\mathrm{P}^{\mathrm{B}}$ (I). As an example, this analysis was performed for a series of 64 replicate pairs of $\mathrm{P}^{\mathrm{B}}(\mathrm{I})$ from surface samples off the southwest coast of Vancouver Island. $\mathrm{P}^{\mathrm{B}}(\mathrm{I})$ ranged from

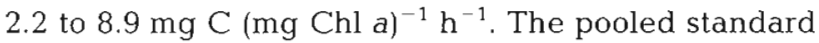
deviation was $0.19 \mathrm{mg} \mathrm{C}(\mathrm{mg} \mathrm{Chl} \mathrm{a})^{-1} \mathrm{~h}^{-1}$. The $95 \%$ confidence limits for a single measurement, calculated from the pooled standard deviation, were $\pm 0.39 \mathrm{mg} \mathrm{C}$ (mg Chl a $)^{-1} \mathrm{~h}^{-1}$.

By examining the relation between $\mathrm{P}_{\mathrm{m}}^{\mathrm{B}}$ and the fitted photosynthetic rate, $\hat{P}^{B}(I)$, in a series of $P(I)$ experiments, through a range of values of I, predictive regression coefficients can be calculated and confidence intervals established for estimates of $\hat{P}_{\mathrm{m}}^{\mathrm{B}}$ made from incubations at these values of I. Fig. 4 shows linear regressions of $\mathrm{P}_{\mathrm{m}}^{\mathrm{B}}$ versus $\hat{\mathrm{P}}^{\mathrm{B}}(\mathrm{I})$ for $\mathrm{I}=50,100,200,325$, $450,750,1250$ and $2000 \mu$ Ein s$~^{-1} \mathrm{~m}^{-2}$, based on all coastal $P(I)$ experiments $(n=72)$ included in this study. Table 3 lists slopes and correlation coefficients for these regressions. The best fit was obtained at $\mathrm{I}=$ $750 \mu$ Ein s$~^{-1} \mathrm{~m}^{-2}$, where the correlation coefficient $\mathrm{r}=$ 0.998 . This corresponds to the irradiance closest to the

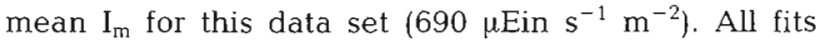
were significant at $\mathrm{p}<0.01$.

Methods for estimating $\hat{P}_{\mathrm{m}}^{\mathrm{B}}$ with a specified probability level from a number of determinations of $\hat{\mathrm{P}}^{\mathrm{B}}(\mathrm{I})$ are given by Sokal \& Rohlf (1969). Fig. 4 includes $95 \%$ prediction limits for estimates of $\hat{P}_{m}^{B}$ from $\hat{P}^{B}(I)$ with a sample size of 2 . This would be a typical situation with paired light and dark bottles. The mean $\hat{\mathrm{P}}^{\mathrm{B}}(750)$ was $7.9 \mathrm{mg} \mathrm{C}(\mathrm{mg} \mathrm{Chl} \mathrm{a})^{-1} \mathrm{~h}^{-1}$. The mean $\pm 95 \%$ prediction limits for $\hat{\mathrm{P}}_{\mathrm{m}}^{\mathrm{B}}$ estimated from $\hat{\mathrm{P}}^{\mathrm{B}}(\mathrm{I})=7.9$ is $8.1 \pm 0.4$ $( \pm 5 \%)$. Across the complete data set contributing to the predictive relation, the mean $\pm 95 \%$ prediction 

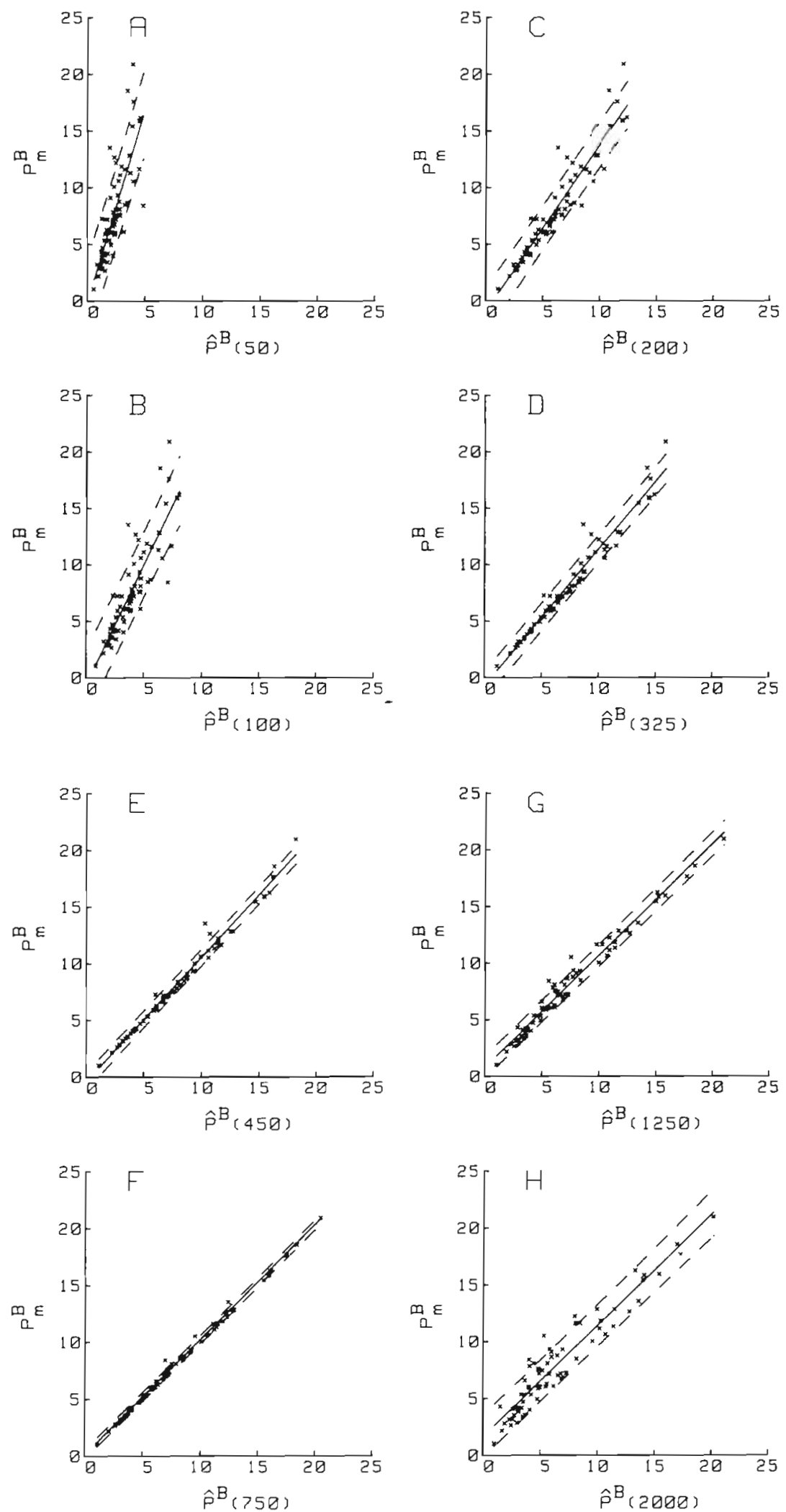

Fig. 4. Linear regressions of $P_{m}^{B}$ on $\hat{P}^{B}(I)$ for $I=50$ (A), 100 (B), 200 (C), 325 (D), 450 (E), 750 (F), 1250 (G) and 2000 (H). Data are from complete coastal data set. Dashed lines are $95 \%$ prediction limits for estimates $\hat{P}_{\mathrm{m}}^{\mathrm{B}}$ from 2 determinations of $\hat{P}^{B}(\mathrm{I})$. Units are $\mathrm{mg} \mathrm{C}(\mathrm{mg} \mathrm{Chl} \mathrm{a})^{-1} \mathrm{~h}^{-1}$ for $\mathrm{P}_{\mathrm{m}}^{\mathrm{B}}$ and $\hat{\mathrm{P}}^{\mathrm{B}}(\mathrm{I})$ and $\mu$ Ein $\mathrm{s}^{-1} \mathrm{~m}^{-2}$ for $\mathrm{I}$ 
Table 3. Slopes and correlation coefficients, $r$, for regressions of $\mathrm{P}_{\mathrm{m}}^{\mathrm{B}}$ on fitted photosynthetic rates, $\hat{\mathrm{P}}^{\mathrm{B}}(\mathrm{I})$, from $\mathrm{P}(\mathrm{I})$ experiments, for a series of values of $I$. All regressions based on the complete set of $\mathrm{P}(\mathrm{I})$ experiments from coastal waters; sample size is 72

\begin{tabular}{|ccc|}
\hline$I\left(\mu\right.$ Ein $\left.~^{-1} \mathrm{~m}^{2}\right)$ & Slope & $r$ \\
\hline 50 & 3.355 & 0.811 \\
100 & 2.126 & 0.878 \\
200 & 1.471 & 0.946 \\
325 & 1.206 & 0.980 \\
450 & 1.097 & 0.992 \\
750 & 1.008 & 0.998 \\
1250 & 0.989 & 0.987 \\
2000 & 0.973 & 0.953 \\
\hline
\end{tabular}

limits of $\hat{P}_{\mathrm{m}}^{\mathrm{B}}$ ranged from $1.2 \pm 0.4( \pm 31 \%)$, where $\hat{\mathrm{P}}^{\mathrm{B}}(750)=1.1$, to $20.8 \pm 0.4( \pm 2 \%)$, where $\hat{\mathrm{P}}^{\mathrm{B}}(750)=$ 20.5 .

A similar approach can be used to obtain estimates of the initial slope, $\hat{\alpha}$, from photosynthetic rate measurements, $\mathrm{P}^{\mathrm{B}}(\mathrm{I})$, at a single irradiance, I. Linear regressions of $\alpha$ on $\hat{\mathrm{P}}^{\mathrm{B}}(\mathrm{I})$ for $\mathrm{I}=50,100,200$ and $325 \mu$ Ein $\mathrm{s}^{-1} \mathrm{~m}^{-2}$ are shown in Fig. 5, with $95 \%$ prediction limits for estimates $\hat{\alpha}$ from $\hat{\mathrm{P}}^{\mathrm{B}}(\mathrm{I})$ with a sample size of 2 . Slopes and correlation coefficients for these regres-
Table 4. Slopes and correlation coefficients, $r$, for regressions of $\alpha$ on fitted photosynthetic rates, $\hat{\mathrm{P}}^{\mathrm{B}}(\mathrm{I})$, from $\mathrm{P}(\mathrm{I})$ experiments, for a series of values of I. All regressions based on the complete set of $\mathrm{P}(\mathrm{I})$ experiments from coastal waters; sample size is 72

\begin{tabular}{|ccc|}
\hline$I\left(\mu\right.$ Ein s $\left.{ }^{1} \mathrm{~m}^{-2}\right)$ & Slope $\left(\mu \operatorname{Ein~s}^{-1} \mathrm{~m}^{-2}\right)$ & $\mathrm{r}$ \\
\hline 50 & $2.406 \times 10^{-2}$ & 0.984 \\
100 & $1.359 \times 10^{-2}$ & 0.949 \\
200 & $8.030 \times 10^{-3}$ & 0.874 \\
325 & $5.837 \times 10^{-3}$ & 0.802 \\
\hline
\end{tabular}

sions are listed in Table 4 . The best fit was obtained at the $50 \mu \operatorname{Ein~s}^{-1} \mathrm{~m}^{-2}(\mathrm{r}=0.984, \mathrm{n}=72)$. Fits at all light levels, including at higher light levels not shown, were significant at $\mathrm{p}<0.01$. The correlation coefficient for $\hat{\alpha}$ on $\hat{\mathrm{P}}^{\mathrm{B}}(2000)$ was 0.613 .

The mean $\hat{\mathrm{P}}^{\mathrm{B}}(50)$ for this data set was $2.4 \mathrm{mg} \mathrm{C}$ ( $\mathrm{mg}$ Chl a) ${ }^{-1} \mathrm{~h}^{-1}$. The $95 \%$ prediction limits for $\hat{\alpha}$, with sample size $\mathrm{k}=2$, at $\hat{\mathrm{P}}^{\mathrm{B}}(50)=2.4$ was $0.058 \pm 0.007$ $( \pm 12 \%) \mathrm{mg} \mathrm{C}(\mathrm{mgChl} a)^{-1} \mathrm{~h}^{-1}\left(\mu \operatorname{Ein~s}^{-1} \mathrm{~m}^{-2}\right)^{-1}$. At the minimum and maximum $\hat{P}^{B}(50)$ values $(0.6$ and $4.9 \mathrm{mg} \mathrm{C}(\mathrm{mg} \mathrm{Chl} \mathrm{a})^{-1} \mathrm{~h}^{-1}$ respectively) the $95 \%$ prediction limits with $\mathrm{k}=2$ were $0.014 \pm 0.007$ ( $\pm 50 \%$ ) and $0.117 \pm 0.007( \pm 6 \%) \mathrm{mg} \mathrm{C}(\mathrm{mgChla})^{-1} \mathrm{~h}^{-1}$ (uEin $\left.\mathrm{s}^{-1} \mathrm{~m}^{-2}\right)^{-1}$ respectively.
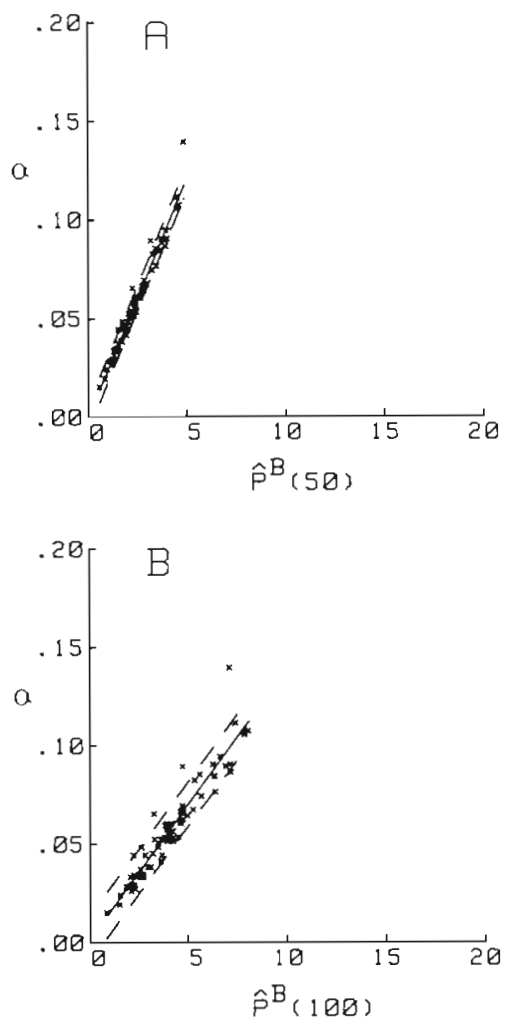
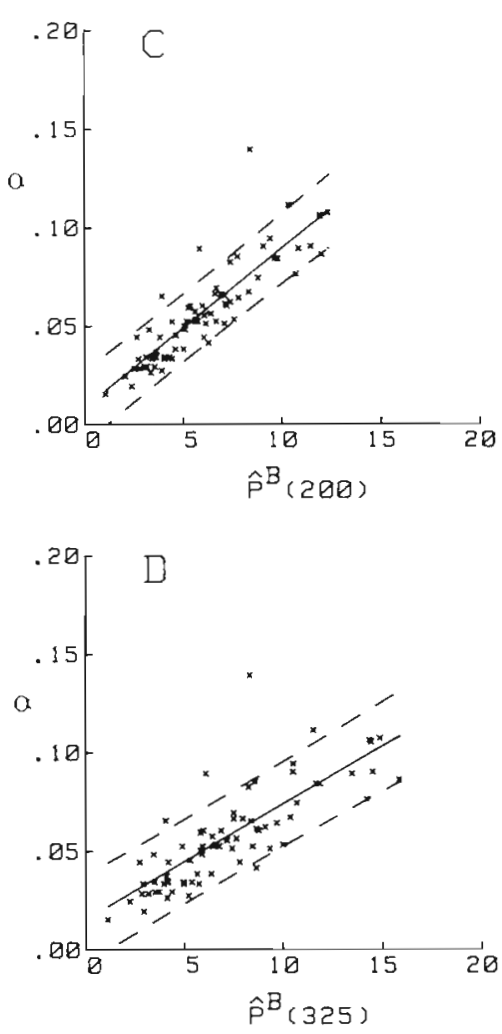

Fig. 5. Linear regressions of $\alpha$ on $\hat{\mathrm{P}}^{\mathrm{B}}(\mathrm{I})$ for $\mathrm{I}=50(\mathrm{~A}), 100(\mathrm{~B}), 200(\mathrm{C})$, and $325(\mathrm{D})$ $\mu$ Ein $5^{-1} \mathrm{~m}^{-2}$. Data are from complete coastal data set. 3ashed lines are $95 \%$ prediction limits for estimates of $\alpha$ from 2 determinations of $\hat{\mathrm{P}}^{\mathrm{B}}(\mathrm{I})$. Units of $\alpha$ and $\hat{\mathrm{P}}^{\mathrm{B}}(\mathrm{I})$ are $\mathrm{mg} \mathrm{C}(\mathrm{mg} \mathrm{Chl} a)^{-1} \mathrm{~h}^{-1}\left(\mu \operatorname{Ein~} \mathrm{s}^{-1}\right.$ $\left.\mathrm{m}^{-2}\right)^{-1}$ and $\mathrm{mg} \mathrm{C}(\mathrm{mg} \mathrm{Chl} \mathrm{a})^{-1} \mathrm{~h}^{-1}$ respectively 


\section{DISCUSSION}

Our samples were collected at the depth of the chlorophyll maximum within the upper mixed layer. That depth ranged from 5 to $25 \mathrm{~m}$, corresponding to light levels from greater than $50 \%$ to less than $5 \%$ of subsurface irradiance at $0 \mathrm{~m}$. Mean buoyancy frequencies at the sampling depths and in the pycnocline are given in Table 5 . These indicate the relative stability

Table 5. Mean buoyancy frequency $N=(-\mathrm{g}[\delta \rho / \delta z] / \rho)^{1 / 2}$ (cph) at sampling depths and in the pycnocline, where $\mathrm{g}=$ $9.81 \mathrm{~m} \mathrm{~s}^{-2}$ and $\rho$ is the density

\begin{tabular}{|lcc|}
\hline \multicolumn{1}{c}{ Region } & N (sample depths) & N (pycnocline) \\
\hline Saanich Inlet & 14.9 & 34.1 \\
Strait of Georgia & 11.8 & 63.9 \\
Hecate Strait & 6.8 & 20.9 \\
\hline
\end{tabular}

of the water column. Typical values for summer pycnoclines range between 20 and $30 \mathrm{cph}$. The extreme value in the Strait of Georgia results from the brackish Fraser River plume overlying more saline coastal water. The degree of mixing inferred from the stability was moderate at sampling locations and depths in Saanich Inlet and the Strait of Georgia, but stronger in Hecate Strait. We consider that photosynthesis was generally limited by available light. Nutrient limitation may have affected populations at some stations in Hecate Strait where nitrate was undetectable at sample depths. Elsewhere, analyses of ambient concentrations provided no evidence of nutrient limitation.

Before considering the impact of variability of photosynthetic parameters on determinations of photosynthetic capacity, we shall discuss some specific problems associated with these parameters in the absence of photoinhibition, and assess the validity of the procedure for determining the correlation between parameters. Analytical problems are encountered with the derived parameters $\mathrm{P}_{\mathrm{m}}^{\mathrm{B}}$ and $\mathrm{I}_{\mathrm{m}}$ where there is no photoinhibition. As $\beta \rightarrow 0, P_{\mathrm{m}}^{B} \rightarrow \mathrm{P}_{\mathrm{s}}^{\mathrm{B}}$ (Platt et al. 1980) and $I_{m}$ becomes undefined. This problem can be circumvented in the absence of photoinhibition by using a 2-parameter model, such as that of Jassby \& Platt (1976). However, where data from a number of $P(I)$ experiments are to be compared, some of which exhibit photoinhibition, we prefer to use a single model. In the 3 -parameter model, where $\beta \neq 0, \mathrm{P}_{\mathrm{s}}^{\mathrm{B}}$ is effectively a virtual or imaginary parameter and is not suitable as a measure of photosynthesis. The approach we have taken is to use $P_{\mathrm{m}}^{B}$ in all cases, with the understanding that it is in fact $P_{\Im}^{B}$ when $\beta=0$. While the lack of an apparent diel cycle of $I_{m}$ could result from its being undefined and hence not well estimated for some experiments, the similar absence of pattern in $\mathrm{I}_{\mathrm{s}}$ and $\mathrm{I}_{\mathrm{k}}$ indicates that the lack of a diel cycle is probably real. The non-cyclic distribution of these parameters follows from the linear covariation of both $\mathrm{P}_{5}^{\mathrm{B}}$ and $\mathrm{P}_{\mathrm{m}}^{\mathrm{B}}$ with $\alpha$.

One consequence of using a non-linear fitting routine to estimate the various parameters simultaneously is that the errors of the individual parameters are not independent. The variances are interrelated such that the confidence limits form a hyperellipsoid in ndimensional space, where $\mathrm{n}$ is the number of parameters. We were concerned about applying standard regression and correlation procedures to $\mathrm{P}_{\mathrm{m}}^{\mathrm{B}}$ and $\alpha$ because of the possibility that the errors in the individual parameters might be correlated. This would be indicated by the major axis of the hyperellipsoid not being normal to any of the parameter axes. While it was not possible to assess directly the validity of the observed correlation of $\mathrm{P}_{\mathrm{m}}^{\mathrm{B}}$ and $\alpha$, since $\mathrm{P}_{\mathrm{m}}^{\mathrm{B}}$ is a derived parameter, we performed a more detailed analysis of the relation between $P_{s}^{B}$ and $\alpha$. We found that the correlation of errors in $\mathrm{P}_{\mathrm{s}}^{\mathrm{B}}$ and $\alpha$ was uniformly negative, contrary to the correlation of the coefficients or parameters, which was positive. In most cases the correlation of errors was significant at $p=0.05$. Approximate $95 \%$ joint confidence regions (Silvert 1979) for $P_{s}^{B}$ and $\alpha$ were plotted for the coastal $P(I)$ experiments (Fig. 6). Boundaries for each joint confidence region were calculated with $\beta$ held at its optimized value for that particular experiment. The family of joint confidence regions defines an envelope

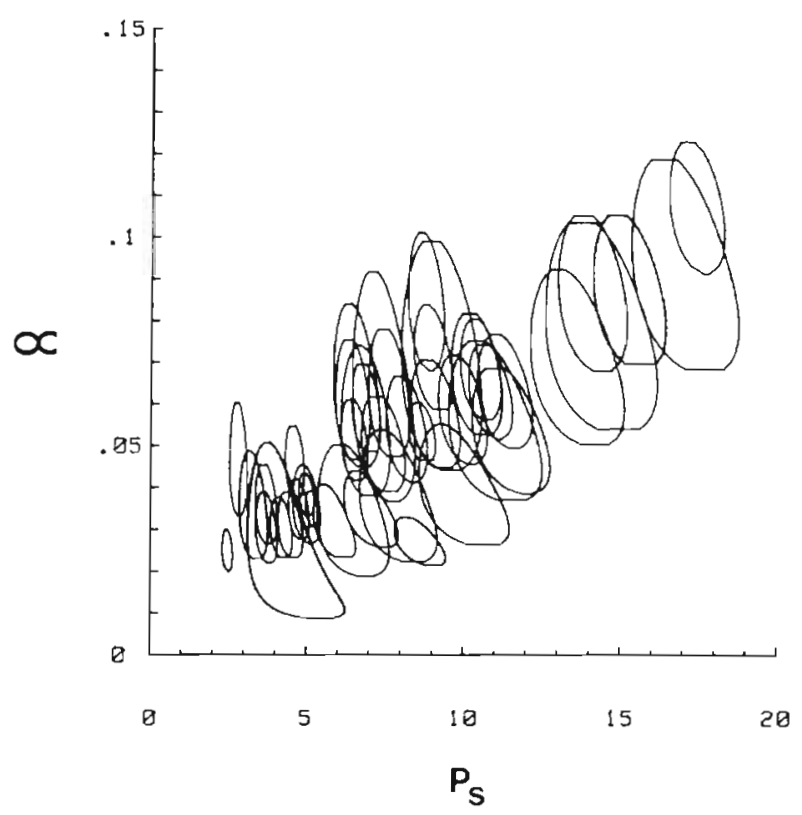

Fig. 6. 2-dimensional approximate joint confidence regions for estimates of $P_{s}^{6}$ and $\alpha_{1}$ calculated with $\beta$ at its optimum. Confidence regions are artificially truncated to a small degree at their upper and lower bounds 
in 2-dimensional ( $P_{s}^{B}$ and $\alpha$ ) space within which values of these parameters can be expected to fall. The orientation of this envelope confirms the positive covariation of $\mathrm{P}_{5}^{\mathcal{B}}$ and $\alpha$ determined through regression analysis. The possibility that this pattern might be distorted at non-optimum values of $\beta$ was investigated by plotting the 3 -dimensional $\left(\mathrm{P}_{s,}^{\mathrm{B}} \alpha\right.$ and $\beta$ ) joint confidence regions for 4 experiments spanning the range of observed $\mathrm{P}_{\mathrm{s}}^{\mathrm{B}}$ (Fig. 7). The similarity in form and orienta-

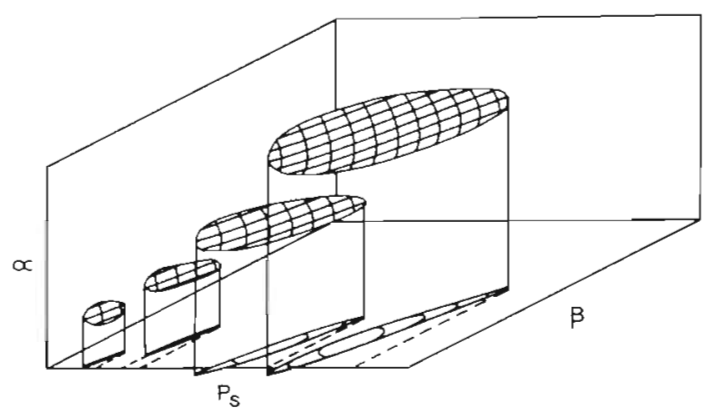

Fig. 7. 3-dimensional approximate joint confidence regions for estimates of $\mathrm{P}_{s i}^{\mathrm{B}} \alpha$ and $\beta$ from selected $\mathrm{P}(\mathrm{I})$ experiments. Regions are projected on to the $\mathrm{P}_{\mathrm{s}}^{\mathrm{B}} / \beta$ plane

tion of these confidence regions indicates that our conclusion is not affected by the value of $\beta$. In view of the strong correlation between $\mathrm{P}_{\mathrm{s}}^{\mathrm{B}}$ and $\mathrm{P}_{\mathrm{m}}^{\mathrm{B}}$ in our data, we consider that the application of regression analysis to $\mathrm{P}_{\mathrm{m}}^{\mathrm{B}}$ and $\alpha$ is valid.

We also note that the projections of the 3-dimensional joint confidence regions onto the plane of $P_{5}^{B}$ and $\beta$ show that, for any particular value of $\beta$ within the confidence region, the possible range of $P_{s}^{B}$ is small. However, over the full confidence region there is a strong positive correlation of errors for the estimates of $\mathrm{P}_{\mathrm{s}}^{\mathrm{B}}$ and $\beta$. This problem is particularly severe at low values of $\beta$, as it is difficult for the fitting routine to stabilize on a value of $\mathrm{P}_{\mathrm{s}}^{\mathrm{B}}$ in the absence of photoinhibition. Consequently, when $\beta$ is poorly determined, so is $\mathrm{P}_{\mathrm{s}}^{\mathrm{B}}$. In contrast, estimates of $\alpha$ are more independent of estimates of both $\mathrm{P}_{s}^{\mathrm{B}}$ and $\beta$.

The stability of the relation between $\mathrm{P}_{\mathrm{m}}^{\mathrm{B}}$ and $\alpha$ observed in this study is notable in view of: (i) the distance between Hecate Strait and the Strait of Georgia/Saanich Inlet region: some $700 \mathrm{~km}$; (ii) the differences in times of sampling, in situ PAR at sample depths and water column stability as indicated by buoyancy frequencies; and (iii) the large ranges of $\mathrm{P}_{\mathrm{m}}^{\mathrm{B}}$ and $\alpha$ encountered. A significant correlation between $\mathrm{P}_{\mathrm{m}}^{\mathrm{B}}$ and $\alpha$ has been reported frequently (Malone \& Neale 1981, Harding et al. 1982a, 1983, Côté \& Platt 1983). Sources of variation in the relation are not well established; however, evidence suggests that community structure plays a major role, acting through different photoadaptive responses by different taxa
(Falkowski \& Owens 1980, Malone \& Neale 1981, Perry et al. 1981, Côté \& Platt 1983). Phytoplankton biomass was dominated by diatoms in all samples in this study (Denman et al. 1985, unpubl. data). We believe that the discrepancy in effective pore size between the filters used for chlorophyll analysis and photosynthetic rate measurements does not significantly affect our results, as biomass was dominated by cells large enough to be retained by both types of filters. Some stations in the Harding et al. (1982a) study were dominated numerically by dinoflagellates, while others were dominated by diatoms, but no apparent difference was indicated between these groups in the relation between $\mathrm{P}_{\mathrm{m}}^{\mathrm{B}}$ and $\alpha$. The slope of $\alpha$ on $\mathrm{P}_{\mathrm{m}}^{\mathrm{B}}$ for the combined data of this study, $7.04 \times 10^{-3}\left(\mu \operatorname{Ein} \mathrm{s}^{-1} \mathrm{~m}^{-2}\right)^{-1}$, is similar to the value obtained by Harding et al. (1982a) on samples from California coastal waters $\left(8.15 \times 10^{-3}\right)$ using the simultaneous curve-fitting procedure described here. Applying the subjective curve-fitting method of Jassby \& Platt (1976) to the same data set, they obtained a slope of $5.57 \times 10^{-3}$. Lewis \& Smith (1983) have shown that incubation time can significantly affect estimates of photosynthetic parameters, as a result of rapid photoadaptation. It is evident that the observed correlation between $\mathrm{P}_{\mathrm{m}}^{\mathrm{B}}$ and $\alpha$ is strongly affected by experimental technique and by how one estimates the parameters. For useful comparisons to be made between studies it is important to standardize and report methods. Where methods are standardized, $\mathrm{P}_{\mathrm{m}}^{\mathrm{B}}$ is an appropriate index for comparing photosynthetic condition of populations with similar taxonomic structure.

Where sampling strategy requires sampling at different times of day, the diel cycle must be taken into account. This permits normalization of photosynthetic capacity estimates from stations that are separate in time and space to a specific reference time, such as local apparent noon. Similarly, if daily integrated production is to be estimated, Harding et al. (1982b) have demonstrated the necessity of incorporating diel variation into the estimation procedure. For these adjustments, the variability of amplitude, phase and degree of departure from sine form must be established on a spatial and temporal scale suitable to the particular survey area. When determining the form of the cycle, it is important to ensure that the same population is being resampled. Distortion of the diel cycle where strong variations in salinity occurred was observed at an anchor station off Guyana by Cadée (1975). Similar distortion by tidal excursions (Demers \& Legendre 1979) suggests that this problem may be exacerbated in estuarine and nearshore environments. In both cases changes in water masses at the sampling location resulted in corresponding variation in the phytoplankton populations being sampled. Calculation of confidence limits for parameters describing the diel cycle is 
discussed by MacCaull \& Platt (1977). The error in amplitude is an additional source of variance that must be added to the total variance of $\mathrm{P}_{\mathrm{m}}^{\mathrm{B}}$, where either an adjustment to a specific reference time is performed or the diel cycle is incorporated into estimates of integrated production. The form of the cycle observed here was sinusoidal. This is comparable to observations in some studies (e.g. Gargas et al. 1979) but differs from the results of MacCaull \& Platt (1977). Brown \& Field (1985) found considerable variation from day to day in the amplitude and phase of the daily cycle in coastal waters off South Africa. We have not calculated the errors in estimates of amplitude for this data set, as we feel that the spatial and temporal variability of the diel cycle requires more intensive investigation.

When determining photosynthetic capacity without $\mathrm{P}(\mathrm{I})$ experiments, previous investigators have arbitrarily chosen a light level, believed to be saturating, at which to incubate samples. The range of irradiance values that has been used is wide (e.g. approx. 195 $\mu$ Ein s ${ }^{-1} \mathrm{~m}^{-2}$, Malone $1971 ; 375 \mu$ Ein s$^{-1} \mathrm{~m}^{-2}$, Demers \& Legendre $1982 ; 580 \mu$ Ein $\mathrm{s}^{-1} \mathrm{~m}^{-2}$, Gargas et al. 1980). We have demonstrated a method of estimating $\mathrm{P}_{\mathrm{m}}^{\mathrm{B}}$ values and confidence limits from productivity determinations at assay levels that need not necessarily be saturating, based on relations derived from a series of $\mathrm{P}(\mathrm{I})$ experiments. The mean $\mathrm{I}_{\mathrm{m}}$ for this data set was $691 \mu \mathrm{Ein} \mathrm{s}^{-1} \mathrm{~m}^{-2}$, with a range from 300 to $>3000$ $\mu$ Ein $\mathrm{s}^{-1} \mathrm{~m}^{-2}$. The best fit for $\hat{\mathrm{P}}_{\mathrm{m}}^{\mathrm{B}}$ on $\hat{\mathrm{P}}^{\mathrm{B}}(\mathrm{I})$ is found for $\mathrm{I}$ closest to the mean $I_{m}$. The fits at light levels greater than typical $I_{m}$ values are degraded because of the variability in susceptibility of populations to photoinhibition during incubation (Denman \& Marra 1986). Although we found $\alpha$ and $\mathrm{P}_{\mathrm{m}}^{\mathrm{B}}$ to be correlated, variations in $\alpha$ cause increasing degradation of the fits at light levels less than $I_{m}$ as the difference between the irradiance value used for the estimation procedure and $I_{m}$ increases. When choosing a suitable light level to apply this method for the estimation of $\mathrm{P}_{\mathrm{m}}^{\mathrm{B}}$, the best strategy is to choose a value close to the estimated mean $I_{m}$. Where $\alpha$ is to be estimated, Fig. 5 demonstrates that estimates improve as $\mathrm{I} \rightarrow 0$. The lowest assay irradiance commensurate with sufficient precision in estimates of $\hat{P}^{B}(I)$ is best.

Our prediction limits for estimates of $\mathrm{P}_{\mathrm{m}}^{\mathrm{B}}$ from $\mathrm{P}^{\mathrm{B}}(\mathrm{I})$ were calculated using a large range of $\mathrm{P}^{\mathrm{B}}(\mathrm{I})$. In areas where the dynamic range of $P_{m}^{B}$ values is small, particularly where the absolute levels of $\mathrm{P}_{\mathrm{m}}^{\mathrm{B}}$ are low, estimates could be improved by performing a more intensive series of $P(I)$ experiments in this range. As an example, Fig. 8 gives the regression of $P_{m}^{B}$ on $P^{B}(450)$ from a series of $\mathrm{P}(\mathrm{I})$ experiments at Ocean Station in $\mathrm{P}$ in May 1984. $P_{\mathrm{m}}^{\mathrm{B}}$ values in this series spanned the range 0.7 to $3.9 \mathrm{mg} \mathrm{C}(\mathrm{mg} \mathrm{Chl} \mathrm{a})^{-1} \mathrm{~h}^{-1}$. The slope for this set is 0.946 and the correlation coefficient $I$ is 0.992 .

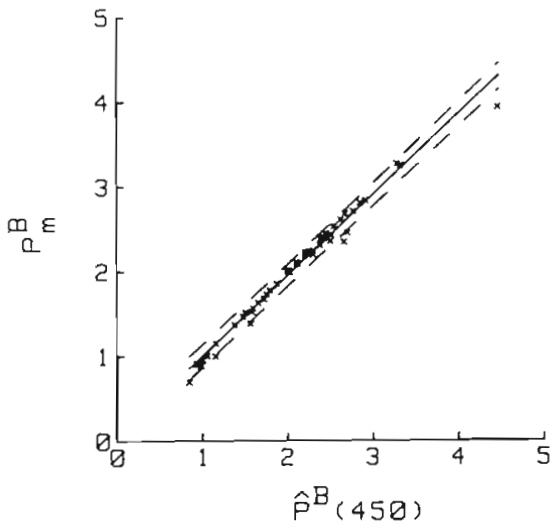

Fig. 8. Linear regression of $\mathrm{P}_{\mathrm{m}}^{\mathrm{B}}$ on $\hat{\mathrm{P}}^{\mathrm{B}}(450)$, with $95 \%$ prediction limits (dashed lines) for estimates of $\hat{P}_{\mathrm{m}}^{\mathrm{B}}$ from 2 determinations of $\hat{P}^{B}(I)$. Data from Ocean Station P. Units are $m g C$ (mg Chl a) ${ }^{-1} \mathrm{~h}^{-1}$

Estimates of $\mathrm{P}_{\mathrm{m}}^{B}$ made from a series of determinations of $\mathrm{P}^{\mathrm{B}}(450)$ at Station $\mathrm{P}$ would be considerably better when the relation derived there was used than if the general coastal series presented above were to be used. For example, the $\hat{\mathrm{P}}_{\mathrm{m}}^{\mathrm{B}} \pm 95 \%$ prediction limit is $1.0 \pm 0.1$ $( \pm 14 \%) \mathrm{mg} \mathrm{C}(\mathrm{mg} \mathrm{Chl} \mathrm{a})^{-1} \mathrm{~h}^{-1}$ for $\hat{\mathrm{P}}^{\mathrm{B}}(450)=1.0 \mathrm{mg}$ $\mathrm{C}(\mathrm{mg} \mathrm{Chl} \mathrm{a})^{-1} \mathrm{~h}^{-1}$.

The techniques outlined above provide a means of estimating errors associated with estimates of photosynthetic capacity and the initial slope of the $P(I)$ curve from assays at a single light level. The differences in relations between photosynthetic parameters between populations over the coastal area we investigated were surprisingly small. In practice, because of unpredictability in community structure and the concomitent variability of relations between parameters and in the diel cycle, we see this technique as applicable over a more restricted spatial scale. It provides for reliable estimation of parameters and confidence limits from large numbers of productivity assays at a single irradiance value, using a relatively small number of full $\mathrm{P}(\mathrm{I})$ experiments to establish appropriate prediction limits for the estimates at the chosen level of irradiance.

Acknowledgements. We thank S. H. Hill, K. A. de Macedo and $H$. A. Sefton for assistance at various stages of this work. The cooperation and assistance of personnel of the C.S.S Vector, C.S.S. Parizeau and C.F.A.V. Endeavour is appreciated.

\section{LITERATURE CITED}

Brown, P. C., Field, J. G. (1985). Diel variation in production rates of natural phytoplankton populations in the Southern Benguela upwelling region. Botanica mar. 28 : 201-208

Cadée, G. C. (1975). Primary production off the Guyana coast. Neth. J. Sea Res. 9: 128-143 
Côté, B., Platt, T (1983). Day-to-day variations in the springsummer photosynthetic parameters of coastal phytoplankton. Limnol. Oceanogr. 28: 320-344

Côté, B., Platt, T (1984). Utility of the light-saturation curve as an operational model for quantifying the effects of environmental conditions on phytoplankton photosynthesis. Mar. Ecol. Prog. Ser. 18: 57-66

Demers, S., Legendre, L. (1979). Effets des marées sur la variation circadienne de la capacité photosynthétique du phytoplancton de l'estuaire du Saint-Laurent. J. exp. mar Biol. Ecol. 39: 87-99

Demers, S., Legendre, L. (1982). Water column stability and photosynthetic capacity of estuarine phytoplankton: longterm relationships. Mar Ecol. Prog. Ser. 7: 337-340

Denman, K, Forbes, R., Mackas, D., Hill, S., Sefton, H. (1985). Ocean ecology data report: British Columbia coastal waters, 29 June-10 July 1983. Can. Data Rep. Hydrogr. Ocean Sci. 36: 1-.77

Denman, K. L., Marra, J. (1986). Modelling the time dependent photoadaptation of phytoplankton to fluctuating light. In: Nihoul, J. C. J. (ed.) Marine interfaces ecohydrodynamics. Elsevier, Amsterdam, p. 341-359

Draper, N. R., Smith, H. (1966). Applied regression analysis. Wiley, New York

Falkowski, P. G., Owens, T G. (1980). Light-shade adaptation: two strategies in marine phytoplankton. Pl. Physiol 66: $592-595$

Forbes, J. R., Sefton, H. A., de Macedo, K. (1983). Phytoplankton productivity experiments in British Columbia coastal waters, 1982 and 1983. Can. Data Rep. Hydrogr. Ocean Sci. 14: 1-193

Gargas, E., Hare, I., Martens, P., Edler, L. (1979). Diel changes in phytoplankton photosynthetic efficiency in brackish waters. Mar. Biol. 52: 113-122

Gargas, E., Mortensen, S., Nielsen, G. E. (1980). Production and photosynthetic efficiency of phytoplankton in the open Danish waters 1975-77. Ophelia, Suppl. 1: 123-144

Grasshoff, K. (1976). Methods of seawater analysis. Verlag Chemie, Weinheim

Harding, L. W., Jr, Prézelin, B. B., Sweeney, B. M., Cox, J. L. (1982a). Diel oscillations of the photosynthesis-irradiance (P-I) relationship in natural assemblages of phytoplankton. Mar. Biol. 67: 167-178

Harding, L. W., Jr., Prézelin, B. B., Sweeney, B. M., Cox, J. L. (1982b). Primary production as influenced by diel periodicity of phytoplankton photosynthesis. Mar. Biol. 67: $179-182$
Harding, L. W., Jr., Meeson, B. W., Tyler, M. A. (1983) Photoadaptation and diel periodicity of photosynthesis in the dinoflagellate Prorocentrum mariaelebouriae. Mar. Ecol. Prog. Ser 13: 73-85

Harrison, W. G., Platt, T (1980). Variations in assimilation number of coastal phytoplankton: effects of environmental co-variates. J. Plankton Res. 2: 249-260

Holm-Hansen, O., Lorenzen, C. J., Holmes, R. W., Strickland, J. D. H. (1965). Fluorometric determination of chlorophyll. J. Cons. perm. int. Explor. Mer 30: 3-15

Jassby, A. D., Platt, T. (1976). Mathematical formulation of the relationship between photosynthesis and light for phytoplankton. Limnol. Oceanogr. 21: 540-547

Lewis, M. R., Smith, J. C. (1983). A small volume, shortincubation-time method for measurement of photosynthesis as a function of incident irradiance. Mar. Ecol. Prog. Ser. 13: 99-102

Lewis, M. R., Warnock, R. E., Platt, T. (1985). Absorption and photosynthetic action spectra for natural phytoplankton populations: implications for production in the open ocean. Limnol. Oceanogr. 30: 794-806

MacCaull, W. A., Platt, T. (1977). Diel variations in the photosynthetic parameters of coastal marine phytoplankton. Limnol. Oceanogr. 23: 723-731

Malone, T. C. (1971). Diurnal rhythms in netplankton and nannoplankton assimilation ratios. Mar. Biol. 10: 285-289

Malone, T. C., Neale, P. J. (1981). Parameters of light-dependent photosynthesis for phytoplankton size fractions in temperate estuarine and coastal environments. Mar. Biol. 61: 289-297

Perry, M. J., Talbot, M. C., Alberte, R. S. (1981). Photoadaptation in marine phytoplankton: response of the photosynthetic unit. Mar. Biol. 62: 91-101

Platt, T., Gallegos, C. L., Harrison, W. G. (1980). Photoinhibition in natural assemblages of marine phytoplankton. J. mar. Res. 38: 687-701

Ricker, W. E. (1973). Linear regressions in fishery research. J. Fish. Res. Bd Can. 30: 409-434

Silvert, W. (1979). Practical curve fitting. Limnol. Oceanogr. 24: $767-773$

Sokal, R. R., Rohlf, F. J. (1969). Biometry. W. H. Freeman and Co., San Francisco

Strickland, J. D. H., Parsons, T R. (1972). A practical handbook of seawater analysis, 2nd edn. Bull. Fish. Res. Bd Can. 167 